\title{
The $360^{\circ}$ of Information Fluency Delivery to Freshman Engineering Students
}

Marian G. Armour-Gemmen

West Virginia University, marian.armour-gemmen@mail.wvu.edu

Robin A.M. Hensel

West Virginia University

Mary L. Strife

West Virginia University, mary.strife@mail.wvu.edu

Follow this and additional works at: https://researchrepository.wvu.edu/faculty_publications

Part of the Engineering Education Commons, Information Literacy Commons, and the Intellectual Property Law Commons

\section{Digital Commons Citation}

Armour-Gemmen, Marian G.; Hensel, Robin A.M.; and Strife, Mary L., "The $360^{\circ}$ of Information Fluency Delivery to Freshman Engineering Students" (2014). Faculty Scholarship. 1136.

https://researchrepository.wvu.edu/faculty_publications/1136 


\section{The 360 of Information Fluency Delivery to Freshman Engineering Students}

\section{Ms. Marian G. Armour-Gemmen, West Virginia University}

Marian Armour-Gemmen has been the Patent \& Trademark Librarian at West Virginia University Libraries since 2003. In this capacity she assists inventors throughout the state of West Virginia. She is also the bibliographer for Mechanical \& Aerospace Engineering as well as for Civil \& Environmental Engineering. Previously she worked as the head of the Physical Sciences Library and as an associate in the Government Documents department. She is a past president of the Patent \& Trademark Resource Center Association. She holds a MLIS from the University of South Carolina, a MA from the University of Michigan, and a BA from Calvin College.

\section{Dr. Robin A.M Hensel, West Virginia University}

Ms. Mary L. Strife, West Virginia University

Mary is the director and senior engineering librarian of the Evansdale Library at West Virginia University, a position she has held since 2002. She has been at WVU since 1995, arriving as Coordinator of Physical Sciences and Math Libraries. Over her 31 year career, she has worked at Cornell and Syracuse Universities, the University of Rochester and SUNY Institute of Technology Utica/Rome. 


\title{
The $360^{\circ}$ of Information Fluency Delivery to Freshman Engineering Students
}

\begin{abstract}
For three years, engineering librarians from West Virginia University (WVU) have been teaching information fluency skills to 700-1000 freshman engineering students per year, using a specific information fluency cycle. The librarians' responsibilities in the Fall 2013 course syllabus included teaching once in each section, providing a two-hour, in-library group sessions to accommodate almost 700 students, delivering an intellectual property Blackboard ${ }^{\mathrm{TM}}$ module for students to complete over a specific period of time, and requiring students to complete a Plagiarism Avoidance Tutorial with quiz. Some of these components are similar to those of past semesters. However, past collection of the data was difficult. Student participation and compliance were increased through greater buy-in by professors, moving the Plagiarism Avoidance Tutorial to the librarians' control, librarians attending weekly faculty meetings, willingness of librarians to migrate a semester early to the new Blackboard ${ }^{\mathrm{TM}}$ with the engineering faculty, and a compressed schedule for the delivery of all information literacy parts (from eleven weeks to six). The increased student participation provides better indicators of learning and demonstrates areas for teaching improvement. Overall, the data have indicated the students' understanding of the use of information and their beginning awareness of the importance of information tools for their success as engineers.
\end{abstract}

\section{Background}

The engineering librarians at WVU reach approximately 1,000 freshman engineering students each year through information fluency instruction provided within the Engineering 101 course taken by all engineering students. The sustainability of this program is rooted in important components: collaboration with faculty and collaboration with students through Problem Based Learning (PBL). PBL enters into all information learning encounters.

In 2011 the engineering librarians worked jointly with the Statler College of Engineering and Mineral Resources Assistant Dean for Freshman Experience to develop information fluency content for the Engineering 101 curriculum. Using a PBL approach, the curriculum has evolved over the past three years and used a combination of venues, including in-person lectures, inlibrary assignments, and online learning modules. An overview of the current format of the information fluency cycle is presented in Appendix A. Despite changes, PBL has remained an important part of the teaching/learning environment. Collaboration has also been an important part in the development of the information literacy curriculum. Weekly meetings with faculty in the Fall 2013 semester allowed for increased dialog and feedback for the course. The discussions in these meetings have brought greater buy-in from the professors as well as requests for changes which have improved sessions as well as increased time stress on librarians. Additionally, greater buy-in from professors increased student participation in the information literacy opportunities provided them.

\section{Literature Review}

Information fluency is an important part of an engineering student's education. Bracke and Critz $^{1}$ (2001) pointed out that "Information literacy instruction for these students should, 
therefore, be specific, context-based, and highly relevant to their current information needs." Information fluency instruction also helps prepare engineers for their professional life.

Rodrigues $^{2}$ (2001) points out information literate engineers produce better reports, have a competitive advantage and find information more quickly. Nerz and Bullard ${ }^{3}$ (2006) discuss the components of information literacy skills across the engineering curriculum including the complexity of resources, plagiarism and proper citation. In the freshman year students are briefly introduced to library resources and proper citation.

The freshman engineering students were exposed to information literacy through various ways throughout their Engineering 101 class, "Engineering Problem Solving I." Through the different learning opportunities the students were exposed to and learned the ALA/ACRL/STS standards ${ }^{4}$. The STS and ABET standards ${ }^{5}$ played a major role in determining the material that was learned. In Table 1, Strife et al $^{6}$, (2013) illustrated the type of outcomes that could be accomplished with ALA/ACRL/STS Standards.

Table 1. Outcomes that can be accomplished with ALA/ACRL/STS standards.

\begin{tabular}{|c|c|}
\hline ALA/ACRL/STS Standard & Outcome \\
\hline $\begin{array}{l}\text { Standard } 1 . \text { The information literate student } \\
\text { determines the nature and extent of the } \\
\text { information needed. }\end{array}$ & - Distinguishes different types of information. \\
\hline $\begin{array}{l}\text { Standard 2. The information literate student } \\
\text { accesses needed information effectively and } \\
\text { efficiently }\end{array}$ & $\begin{array}{l}\text { - Completes exercises using different } \\
\text { information types: books, technical reports, } \\
\text { articles and handbooks. } \\
\text { - Learns how to cite in MLA format. } \\
\text { - Familiarity with four source databases. } \\
\text { - } \text { Finds information in a handbook. }\end{array}$ \\
\hline $\begin{array}{l}\text { Standard 3. The information literate student } \\
\text { critically evaluates the procured information } \\
\text { and its sources, and as a result, decides } \\
\text { whether or not to modify the initial query } \\
\text { and/or seek additional sources and whether to } \\
\text { develop a new research process. }\end{array}$ & $\begin{array}{l}\text { - Evaluates information using ABCD } \\
\text { mnemonic. }\end{array}$ \\
\hline $\begin{array}{l}\text { Standard 4. The information literate student } \\
\text { understands the economic, ethical, legal, and } \\
\text { social issues surrounding the use of } \\
\text { information and its technologies and either as } \\
\text { an individual or as a member of a group, uses } \\
\text { information effectively, ethically, and legally } \\
\text { to accomplish a specific purpose. }\end{array}$ & $\begin{array}{l}\text { - Knows four types of intellectual property. } \\
\text { - Understands the difference between common } \\
\text { knowledge and not so common knowledge. } \\
\text { - Understands plagiarism and how to avoid it. } \\
\text { - Incorporates citations in technical reports. }\end{array}$ \\
\hline $\begin{array}{l}\text { Standard 5. The information literate student } \\
\text { understands that information literacy is an } \\
\text { ongoing process and an important component } \\
\text { of lifelong learning and recognizes the need } \\
\text { to keep current regarding new developments } \\
\text { in his or her field. }\end{array}$ & $\begin{array}{l}\text { Recognizes the importance of using library } \\
\text { information and the need to keep current with } \\
\text { this ever changing and expanding field. }\end{array}$ \\
\hline
\end{tabular}


Although each learning opportunity emphasized different skills and employed different media, PBL was used in each session. Felder and Brent ${ }^{7}$ (2003) discuss the lifelong learning component of the ABET standards as well as the importance of PBL. Detlor ${ }^{8}$ (2012) writes that PBL or active learning type methods, "challenge students to actively engage with information and resources to solve problems and create knowledge." Both Dochy ${ }^{9}$ (2003) and Prince ${ }^{10}$ (2004) stress the importance of PBL or Active Learning in engineering education. Prince and Felder ${ }^{11}$ (2007) provide an overview of different aspects of inductive teaching and learning. Although Prince and Felder (2007) argue that PBL does not a have a "statistically significant effect on academic achievement as measured by exams," this current analysis found a statistically significant change in scores in the pre- and post-tests.

\section{Methodology and Results}

During the three-year implementation, content delivery took several forms, from three one-hour in-class sessions to a mixed media format comprised of one one-hour in-class session, a twohour library experience, and an online module. The amount of time that the librarians have spent in instruction has also varied as demonstrated in Table 2 below.

Table 2. Number of sections, contact hours, and enrollment for the ENGR 101, Engineering Problem-Solving I, course (Fall 2011-Spring 2014).

\begin{tabular}{|l|c|c|c|c|c|c|}
\hline Term & $\begin{array}{c}\# \\
\text { Sections }\end{array}$ & $\begin{array}{c}\text { In-Class } \\
\text { Contact } \\
\text { Hours }\end{array}$ & OCE & $\begin{array}{c}\text { Library } \\
\text { (OCE) } \\
\text { Contact Hours }\end{array}$ & $\begin{array}{c}\text { Total } \\
\text { Teaching } \\
\text { Hours }\end{array}$ & $\begin{array}{c}\text { Approximate } \\
\text { Enrollment }\end{array}$ \\
\hline Fall 2011 & 18 & 3 & 0 & 0 & 54 & 700 \\
\hline Spring 2012 & 3 & 1 & 1 & 1 & 4 & n/a \\
\hline Fall 2012 & 17 & 1 & 36 & 1 & 53 & 646 \\
\hline Spring 2013 & 8 & 1 & 15 & 1.5 & 30.5 & 313 \\
\hline Fall 2013 & 17 & 1 & 32 & 2 & 81 & 677 \\
\hline Spring 2014 & 9 & 1 & 15 & 2 & 39 & 333 \\
\hline
\end{tabular}

Beginning in Fall 2012, librarians visited the classroom for a one hour session. An in-library workshop was carefully structured to focus the student responses. Controls included assigning relevant preselected and researched topics, stepping the students from simple to complex databases, creating and using a carefully structured worksheet, and using a carefully chosen handbook topic for the students to research. The designed workshop allowed the librarians to assist students better when encountering unanticipated technological problems such as the loss of the online catalog, and incompatibility of browsers with certain databases.

Data were collected around the information fluency instruction cycle. The collected data to be analyzed included pre- and post-test scores, plagiarism test scores, and Intellectual Property module participation rates. The pre-test was administered at the beginning of the cycle and the post test at the end of the cycle (during week seven or eight). The comparison of these test scores yielded an indicator of the efficacy of the information fluency instruction. A plagiarism avoidance tutorial was administered followed by a test, and data were gathered from this test. Analysis of these test scores focus on the questions that demonstrated mastery or were answered 
incorrectly most often. Students received credit for participation after sending plagiarism quiz results to the librarians, completing the in-session worksheet, and emailing of a full-text article related to their search assignment.

A twenty question pre-test was administered before information fluency was introduced in class by librarians. This pre-test served as a baseline for the knowledge the students brought to the course. As shown in Appendix B, pre- and post-test questions included different areas of information fluency. At midterm, after the information fluency had been introduced to the students and they had participated in both an in-library workshop and an online intellectual property module, the students were given the post-test which was identical to the pre-test. Past student participation in the post-test was minimal. This fall, $90 \%$ of the students participated in the post test since it was a required part of the midterm. Individual section results are shown in Figure 1, below.

\section{Comparison of Pre- and Post-Test Scores by Section}

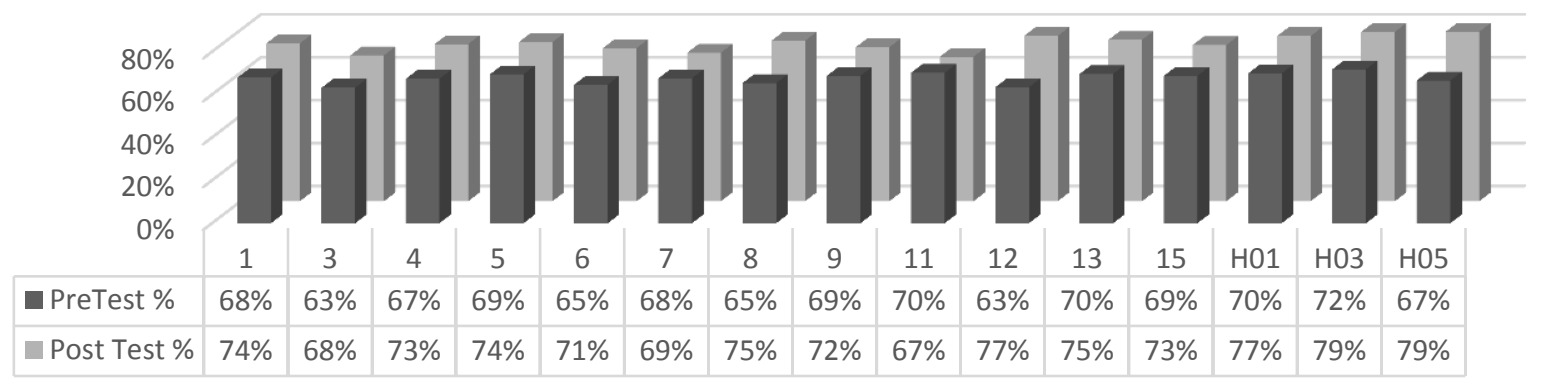

Figure 1. Comparison of Information Fluency Pre- and Post-Test Scores by Course Section.

Of the 15 sections analyzed, only one section had a higher average score on the pre-test than on the post-test. Overall the students significantly improved an average of $6 \%$ over the pre- and post-tests, demonstrating the efficacy of the information fluency instruction.

The importance of the Plagiarism Avoidance Tutorial is growing on campus. The engineering deans are requiring new graduate students to take it. $\mathrm{Yeo}^{12}$ (2007) provides an excellent overview of plagiarism issues confronting engineering students. She points out that many students suggest that plagiarism is highly prevalent in engineering students. The Plagiarism Avoidance Tutorial (http://www.libraries.wvu.edu/instruction/plagiarism/) was administered this fall during the in-library session. In previous semesters students had difficulty in submitting their scores. Additionally, a bug was found in the tutorial and subsequently fixed in Summer 2013. Since the librarians wanted to ensure that the bug was indeed fixed, it was decided to assist students in registering for the tutorial and to assist them in reporting their score from the tutorial. Even though this in-library session was required, only 477 out of 634 participated (75\%). In the in-class session librarians covered "when to cite" an article and common knowledge. The tutorial covered additional information. The tutorial was then followed by a 15 question quiz. Thirty minutes were allowed for the tutorial and quiz. 


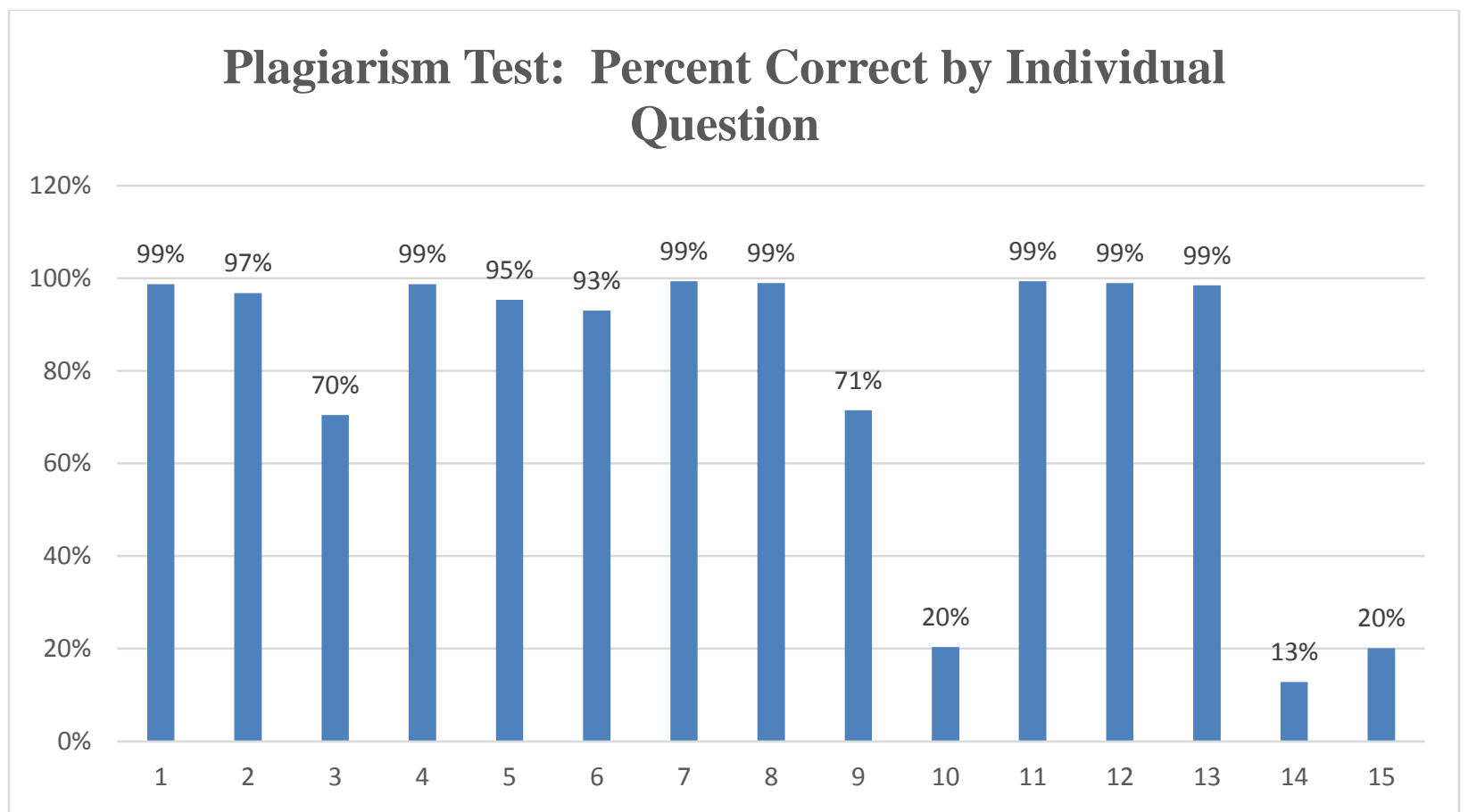

Figure 2. Comparison of student performance (percent correct responses) for each question of the plagiarism test.

Students had significant difficulty with three questions $10,14,15$, all of which had to do with quoting and paraphrasing. Only $20 \%, 13 \%$, and $20 \%$ of students, respectively, correctly answered these questions. Questions 3 and 9 also posed some difficulty with $70 \%$ and $71 \%$ students answering correctly. Question 3 and 9 were both posed in the negative and therefore might have caused confusion.

The Intellectual Property module was followed by a quiz. During the first year of the library participation in Engineering 101, a class session was set aside for the librarians to cover intellectual property including trade secrets, copyright, trademark, and patents. Since the professors felt it took too much time away from class, the lecture was converted to a module in Blackboard. The module included an assigned reading, four PowerPoint sections and a quiz. The only way to determine whether students have viewed the module is to look at the quiz participation. 


\section{Spring 2013 IP Module Completion}

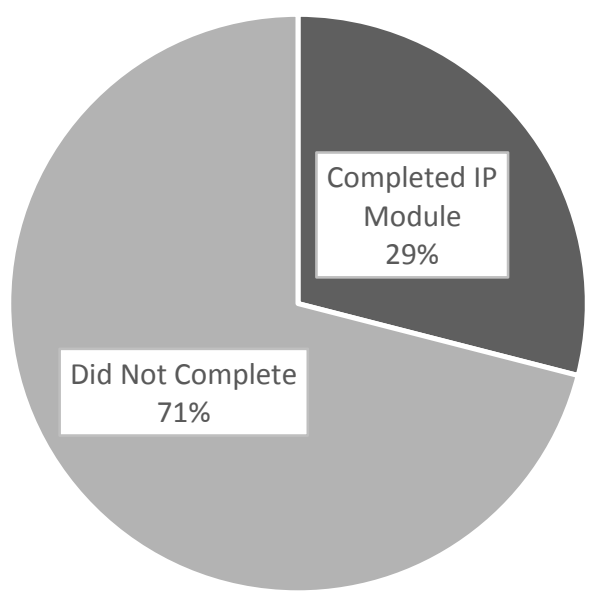

Figure 3. Percent of students who completed the online Intellectual Property module during Spring 2013.

\section{Fall 2013 IP Module Completion}

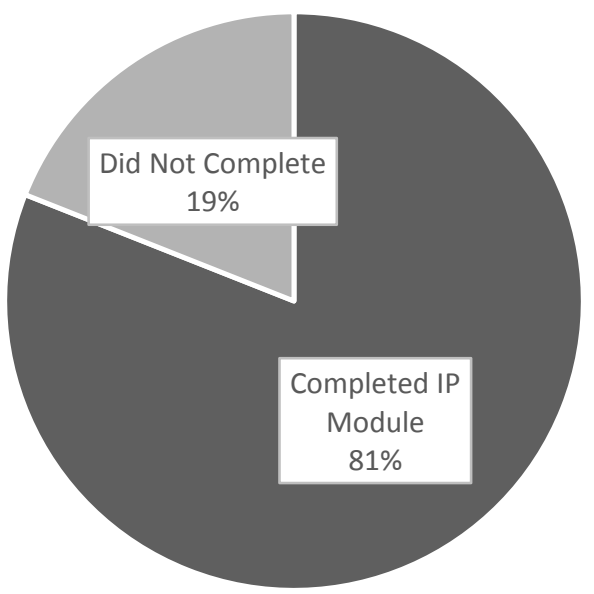

Figure 4. Percent of students who completed the online Intellectual Property module in Fall 2013.

In Spring 2013 it was obvious that only certain sections were participating in the quiz with the overall participation rate of $29 \%$. In the meetings with the engineering faculty in preparation for Fall 2013, librarians informed them about the lack of participation in the quiz. The quiz was then emphasized by the professors and in the fall there was an $81 \%$ participation rate in the quiz. The increase in participation indicated the importance of emphasizing to professors all aspects of information fluency provided by librarians to Engineering 101 students.

The participation rate difference is also evident when analyzing student completion of the Intellectual Property module quiz by section. 


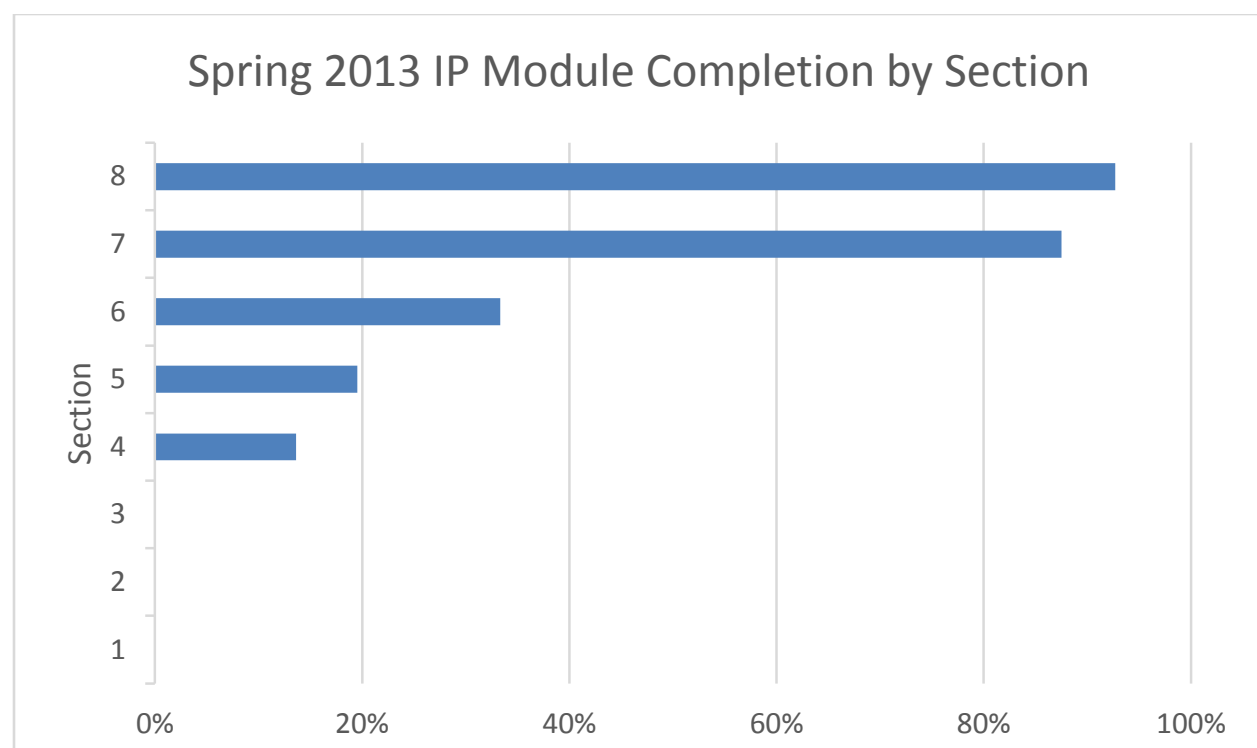

Figure 5. Percent of students per section who completed the online Intellectual Property module in Spring 2013.

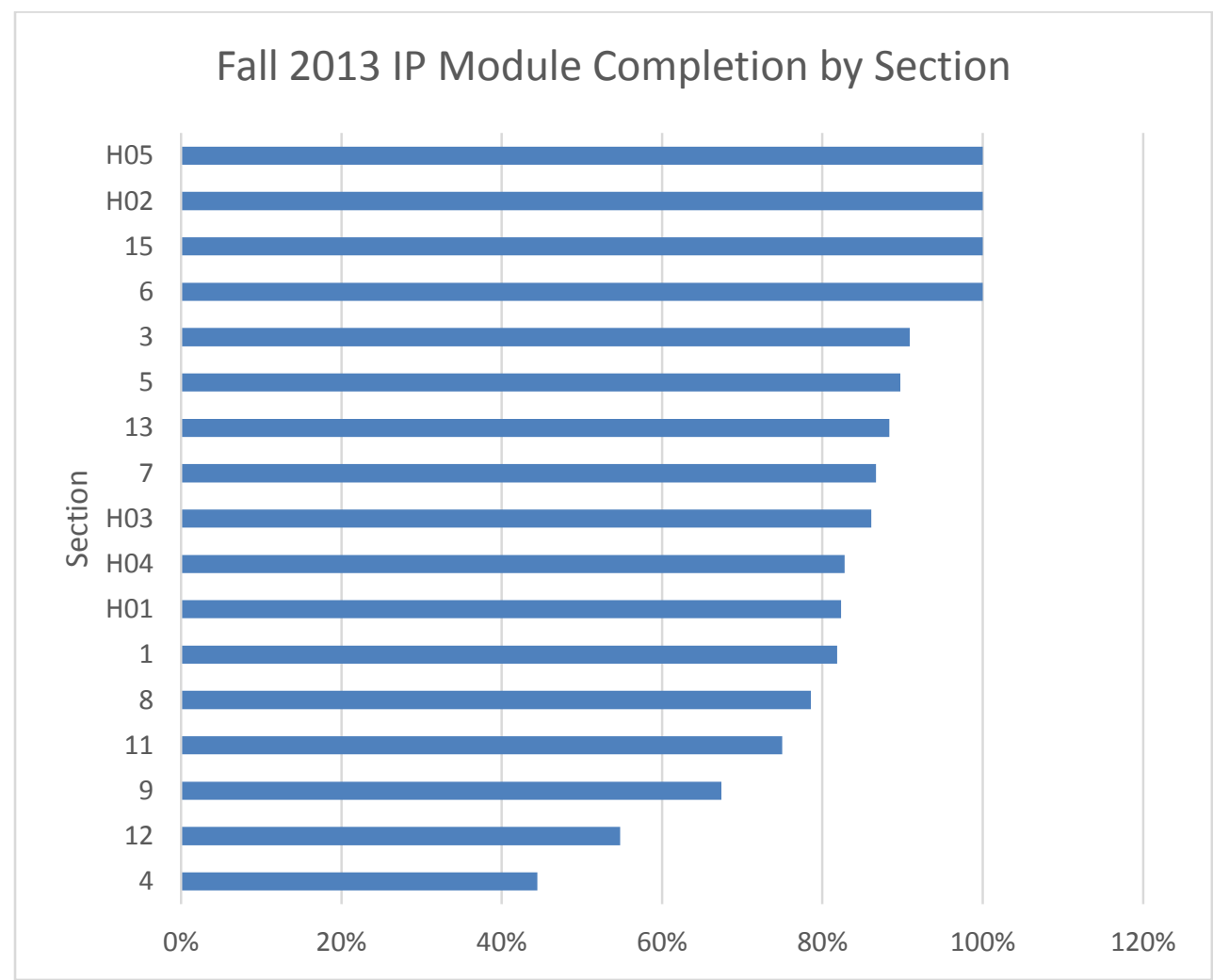

Figure 6. Percent of students per section who completed the online Intellectual Property module in Fall 2013.

In Spring 2013, only five of the eight sections participated in the Intellectual Property module. And the overall completion rate was $29 \%$. After the librarians met with the instructors before Fall 2013, the instructors emphasized the importance of the Intellectual Property module 
completion and informed the students that the Intellectual Property content would be included on the midterm exam. In the 17 sections taught in Fall 2013, four sections had 100\% completion, eight sections had over $80 \%$ completion, and the overall completion rate rose to $81 \%$.

An in-library workshop was carefully structured to control student responses through the training exercises. Besides administering the Plagiarism Avoidance Tutorial during the in-library workshop, the students were given a worksheet to complete during the session. The worksheet corresponded to the different databases that were introduced to the students and incorporated active learning concepts. The worksheet contained fill-in-the-blank format for a MLA citation for each resource they located. This type of format provides a way for the students to look at a citation in a given database and convert it with somewhat ease to MLA format. Carefully chosen topics were assigned to each student to match both resources and possible topics for projects. The librarian tested each topic in all the resources before the instruction session. As Prince and Felder ${ }^{11}$ (2007) point out, "Problem-based learning is arguably the most difficult to implement of all the inductive teaching methods. It is time-consuming to construct authentic open-ended problems whose solution requires the full range of skills specified in the instructor's learning objectives." Constructing a carefully prepared worksheet was worth the effort. The students were stepped through carefully chosen databases: the library catalog, with emphasis on eBooks; SciTech Connect (http://www.osti.gov/scitech/) for technical reports; and Compendex. While using Compendex students were instructed to email the librarian a full-text article that they found. Finally, the students were shown how Knovel provides an interface to search multiple handbooks at one time for terms. The students were then given a book to search for a topic and were instructed to draw a graph from the handbook. The carefully designed workshop allowed the librarians to assist students better when encountering unanticipated technological problems such as the loss of the online catalog, and incapability of browsers with certain databases. One student's response after the in-library session was, "I can't believe how easy it is to use library resources."

\section{Discussion and Conclusion}

Communication and collaboration with faculty made a significant difference in student participation. This improvement furnished more data to be used for assessment. The data from the pre- and post-tests indicate that the instruction was effective. All the components engage the students along the information fluency cycle; and the efficacy of this instruction is demonstrated in the post-test scores. Overall, the data indicate the students' understanding of the use of information and their beginning awareness of the importance of information tools for their success as engineers.

Modifications to each of these instructional components will continue. Based on discussions with faculty about perceived vagueness of questions or expected answers, the librarians evaluated the test questions compared to the instruction content of sessions. Based on this evaluation, the pre- and post-tests for Spring 2014 were updated with three questions clarified and three new questions substituted (see Appendix B). The librarians will continue to discuss the Plagiarism Avoidance Tutorial with the tutorial administrator. The administrator recently agreed to change one question. The librarians are still considering creating a plagiarism tutorial based on engineering student needs. The intellectual property module will need to be revised this 
summer since the United States Patent and Trademark Office has introduced a new classification system.

The data indicate that the current information fluency instruction in Engineering 101 is effective. Students have demonstrated a level of mastery in information fluency skills which will benefit them not only during college but throughout their professional career. The librarians will continue to partner with the freshman engineering instructors to make sure that the information fluency portions of the course integrate well with the syllabus while giving them data to continue to assess what the students are learning. 


\section{Bibliography}

1. Bracke, M. S., \& Critz, L. J. (2001). Re-envisioning instruction for the electronic environment of a 21 st century science-engineering library. Science \& Technology Libraries, 20(2), 97-106. doi:10.1300/J122v20n02_09

2. Rodrigues, R. J. (2001). Industry expectations of the new engineer. Science \& Technology Libraries, 19(3), 179188. doi:10.1300/J122v19n03_12

3. Nerz, H., \& Bullard, L. (2006). The literate engineer: Infusing information literacy skills throughout an engineering curriculum. Paper presented at the 113th Annual ASEE Conference and Exposition, June 18-21, 2006.

4. The ALA/ACRL/STS task force on information literacy for science and technology. Information literacy standards for science and Engineering/Technology. (2006). Retrieved February 16, 2014, from http://www.ala.org/acrl/standards/infolitscitech

5. Criterion 3. Student outcomes. ABET, Engineering accreditation commission. (2012). Criteria for accrediting engineering programs, ABET engineering accreditation commission (http://www.abet.org/uploadedFiles/Accreditation/Accreditation_Step_by_Step/Accreditation_Documents/Current/2 013 - 2014/eac-criteria-2013-2014.pdf ed., pp. 3) ABET.

6. Strife, M. L., Armour-Gemmen, M., \& Hensel, R. A. M. (2013). Re-tooling information instruction delivery and assessment for the freshman engineering class: The good, the bad and the ugly. Paper presented at the 120th ASEE Annual Conference and Exposition, June 23 - June 26, 2013.

7. Felder, R. M., \& Brent, R. (2003). Designing and teaching courses to satisfy the ABET engineering criteria. Journal of Engineering Education, 92(1), 7-25. Retrieved from http://search.ebscohost.com/login.aspx?direct=true \&db=a9h\&AN=48056709\&site=ehost-live

8. Detlor, B., Booker, L., Serenko, A., \& Julien, H. (2012). Student perceptions of information literacy instruction: The importance of active learning. Education for Information, 29(2), 147-161. Retrieved from http://search.ebscohost.com/login.aspx?direct=true \&db=a9h\&AN=80731478\&site=ehost-live

9. Dochy, F., Segers, M., Van, d. B., \& Gijbels, D. (2003). Effects of problem-based learning: A meta-analysis. Learning \& Instruction, 13(5), 533. doi:10.1016/S0959-4752(02)00025-7

10. Prince, M. (2004). Does active learning work? A review of the research. Journal of Engineering Education, 93(3), 223-231. Retrieved from http://search.ebscohost.com/login.aspx?direct=true \&db=a9h\&AN=48056773\&site=ehost-live

11. Prince, M., \& Felder, R. (2007). The many faces of inductive teaching and learning. Journal of College Science Teaching, 36(5), 14-20. Retrieved from http://search.ebscohost.com/login.aspx?direct=true\&db=ehh\&AN=24359797\&site=ehost-live

12. Yeo, S. (2007). First-year university science and engineering students' understanding of plagiarism. Higher Education Research \& Development, 26(2), 199-216. doi:10.1080/07294360701310813 
Appendix A: Information Fluency Delivery

Engineering 101

\begin{tabular}{|c|c|c|c|}
\hline Week & PBL Exercises & Assessments & Reading \\
\hline $\begin{array}{l}\text { Beginning of } \\
\text { Class }\end{array}$ & & $\begin{array}{l}\text { Pre-Test: } \\
\text { Library } \\
\text { Information }\end{array}$ & \\
\hline $\begin{array}{l}\text { Week } 4 \\
\text { "Intro to } \\
\text { Information" }\end{array}$ & $\begin{array}{l}\text { Plagiarism } \\
\text { scenarios } \\
\text { When to cite } \\
\text { scenarios } \\
\text { Identify parts of a } \\
\text { citation }\end{array}$ & & \\
\hline $\begin{array}{l}\text { Week 5-7 } \\
\text { OCE } \\
\text { "Information } \\
\text { Tools" }\end{array}$ & $\begin{array}{l}\text { Worksheet with } \\
\text { citations and graph } \\
\text { Plagiarism } \\
\text { Tutorial }\end{array}$ & $\begin{array}{l}\text { Plagiarism } \\
\text { Quiz } \\
\text { In-session } \\
\text { worksheet }\end{array}$ & \\
\hline $\begin{array}{l}\text { Week 5-7 } \\
\text { eCampus Module } \\
\text { "Intellectual } \\
\text { Property" }\end{array}$ & $\begin{array}{l}\text { Name that } \\
\text { trademark } \\
\text { Find that patent }\end{array}$ & $\begin{array}{l}\text { Intellectual } \\
\text { Property } \\
\text { Quiz }\end{array}$ & $\begin{array}{l}\text { Rockman, H. (2004). } \\
\text { Overview of Intellectual } \\
\text { Property Law. In } \\
\text { Intellectual Property Law } \\
\text { for Engineers and Scientists. } \\
\text { (pp. 1-8). Hoboken: IEEE } \\
\text { Press. }\end{array}$ \\
\hline Midterm & & $\begin{array}{l}\text { Post-Test: } \\
\text { Library } \\
\text { Information }\end{array}$ & \\
\hline
\end{tabular}


Appendix B.

Library Pre-Test, Post-Test Spring 2014

1. A Patent is:

a. A form of protection provided to authors of original works of authorship including literary ... and certain other intellectual works, both published and unpublished.

b. A word, name, symbol, or device that is used in trade with goods to indicate the source of goods and to distinguish them from the goods of others.

c. A device or technique used in a particular trade or (transf.) occupation and giving an advantage because not generally known.

d. A. property right granted to an inventor to exclude others from making, using, offering for sale, or selling the invention.

Answer:

2. Copying and pasting from the Internet can be done without citing the Internet page, because everything on the Internet is common knowledge and can be used without citation.

a. True

b. False

Answer:

3. SciTech Connect is primarily a database for finding
a. Patents
b. Books
c. Journal Articles
d. Technical Reports

Answer:

4. Intellectual Property laws are in place to:

a. Define intellectual creations that are entitled to protection.

b. Define how to obtain or lose intellectual property rights.

c. Define how to obtain enforcement and compensation when the rights are violated.

d. All of the answers.

Answer:

5. It is important to cite all work you use in your papers to:

a. To prove that your work has a solid, scholarly basis.

b. To show the research you have done and allow others to locate the material themselves.

c. To give credit to the author and avoid plagiarism.

d. All of the answers.

Answer: 
6. Of the following types of information, which one does NOT need to be cited?

a. A word-for-word quotation from The New York Times online about economic recovery.

b. A photograph of Rosa Parks that you found in Women in World History: A Biographical Dictionary.

c. A paragraph you wrote summarizing information from a Newsweek article about bioengineered food.

d. A list of three most important things you think students can do to succeed in college. Answer:

7. To what does the following citation refer?

Hoffman, Peter. Tomorrows energy: hydrogen, fuel cells, and the prospects for a cleaner planet. Cambridge, MA: MIT Press, 2001. Print.
a. A journal article.
b. A book.
c. A chapter in a book.
d. Newspaper article.

Answer:

8. Trademarks are directed toward protection of:
a. Manufacturer's or service provider's goodwill and reputation.
b. Book or manuscript.
c. Software.
d. Musical composition.

Answer:

9. Which database was created specifically for engineers?
a. Compendex
b. Academic Search Complete
c. Web of Science
d. Science Direct

Answer:

10. What is the best way to find an article on a given subject?
a. Page through print volumes of academic journals.
b. Search the Web search engine Google or Yahoo.
c. Search an online database like IEEE or Compendex.
d. Search the online library catalog. 
11. What is the most effective prior art patent search?
a. Keyword Searching
b. Classification Searching
c. Google
d. Subject Searching

Answer:

12. When can you copy a chart into your technical report?
a. When you found it in your textbook.
b. When you found it on the Internet.
c. When you cite the orginal.
d. When your friend used it for a different class.

Answer:

13. When evaluating a resource which is NOT a reason for selecting the resources for an engineering class?
a. Author affiliation
b. Recent copyright date
c. Featured as a cover article in Newsweek
d. Includes a bibliography

Answer:

14. Which library tool searches all library resources in one place?
a. Knovel
b. SciTech Connect
c. Compendex
d. Summon

Answer:

15. When would you search for patents?
a. To find out about a specific patent.
b. To learn about recent inventions in a particular field.
c. To find out if your invention has already been patented.
d. All of the answers.

Answer:

16. Which is of the following is a scholarly journal
a. Engineering News Record
b. Newsweek
c. Journal of Heat Transfer 
d. Chemical marketing reporter

Answer:

17. Which of the following are advantages of scholarly articles available by library subscription over free resources available over the Internet?

a. They have passed a peer review by one or more professionals with academic credentials in that scholarly discipline.

b. They have been indexed by professional catalogers to allow retrieval of all relevant articles on a given topic.

c. They cite other scholarly work upon which their research is based, allowing readers to verify methodology and trace related research.

d. All of the above.

e. None of the above.

Answer:

18. You are in a class where the professor requires that your research be strictly based on scholarly resources. Which of the following search/engines/databases would be appropriate for you to use?
a. Bing
b. Yahoo!
c. Wikipedia
d. All of the answers
e. None of the answers

Answer:

19. Miller, Jerrod refers to what in the following citation?

Miller, Jerrod. "Evaluating Soil Genesis And Reforestation

Success On A Surface Coal Mine In Appalachia." Soil Science Society of America Journal 76.3 (2012), 950-960: Web. 24 July 2012.
a. The title of the article
b. The title of the journal
c. The author
d. The volume

Answer:

20. To what does this citation refer:

Thompson, Kelsey R., et al. "Distracted Driving In Elderly And Middle-Aged Drivers." Accident Analysis and Prevention 45 (March 2012): 711-717. Print.
a. A journal article
b. A book 
c. A chapter in a book

d. A newspaper article

Answer: 